\title{
Trade liberalisation and the nutrition transition: mapping the pathways for public health nutritionists
}

\author{
Anne Marie Thow* \\ Menzies Centre for Health Policy, Victor Coppleson Bldg (D02), University of Sydney, NSW 2006, Australia
}

Submitted 18 April 2008: Accepted 26 March 2009: First published online 12 May 2009

\begin{abstract}
Objective: To describe pathways through which trade liberalisation affects the food environment, relevant to the nutrition transition, in order to enable public health nutritionists to understand trade policy as a macro-level influence on food consumption.

Design: The pathways mapped in the present paper are based on the agreements of the World Trade Organization, which shape national policy. Implications for nutrition are presented based on a comprehensive literature review, and case studies are used to illustrate the various pathways.

Setting: Developing countries are currently experiencing a nutrition transition, resulting in dietary patterns associated with chronic disease. Chronic diseases are amenable to prevention, and trade policy has been highlighted as a potential avenue for nutrition-related prevention.

Results: Trade liberalisation influences the food environment through facilitating trade in goods and services, enabling investment and decreasing support/protection for domestic industry. These policy outcomes facilitate the nutrition transition particularly through increasing the availability and affordability of processed foods and animal products. The framework highlights the complex relationship between trade policy and the nutrition transition, with both negative and positive outcomes arising from different aspects of trade liberalisation.

Conclusions: Policy change associated with trade liberalisation has created incentives for consumption patterns associated with the nutrition transition, but has also had some positive nutritional outcomes. As a result, it is important for public health nutritionists to consider the implications of trade policy decisions in their efforts to prevent and control diet-related chronic diseases.
\end{abstract}

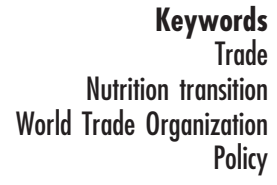

With the creation of the World Trade Organization (WTO) in 1994, trade liberalisation leapt into the global consciousness. Ever since, the implications of trade liberalisation for public health have been hotly debated. Issues such as reductions in access to sanitation, health-care and essential medicines and food safety concerns have been widely discussed ${ }^{(1-3)}$. There is widespread agreement that such downstream - and often unintended - consequences of trade policy making for health must be identified and described in order to ensure that appropriate complementary policies can be developed ${ }^{(4)}$.

A further health implication of the trade liberalisation agenda is the facilitation of unhealthy consumption patterns related to the nutrition transition ${ }^{(4-8)}$. This transition is of growing concern in developing countries, where an observed convergence towards diets high in fat (particularly saturated fat) and sugar, and low in fibre has accompanied a rising burden of chronic disease ${ }^{(9,10)}$. In food terms, this has occurred through increased consumption of processed foods, animal products, vegetable oil and refined grains, in conjunction with reduced consumption of starchy staples ${ }^{(10)}$. Eighty per cent of chronic disease deaths occur in developing countries, and this global epidemic is robbing developing nations of their productive workforce ${ }^{(11)}$. However, diet-related chronic diseases are highly amenable to prevention through healthy diets, and international organisations are recommending intervention at all levels - including through trade policy ${ }^{(12,13)}$. Despite this, there has been no systematic documentation of how the policies and processes of trade liberalisation, as embodied by the agreements of the WTO, influence the nutrition transition ${ }^{(4)}$.

The WTO is the global forum for trade policy direction setting. The agreements of the WTO establish a negotiated basis for national trade policy making, which creates a more integrated global economy ('trade liberalisation'). The aim of trade liberalisation is to improve economic growth through allowing countries to specialise in their production of goods and services, and trade with each other. There are several forums through which trade liberalisation occurs: multilateral WTO negotiations, regional and bilateral free 
trade agreements (FTA), negotiations for WTO accession (countries acceding are required to liberalise trade policies in line with current WTO agreements and negotiation with current members) and liberalisation of policies as a component of loan conditionalities of international financial institutions (particularly the International Monetary Fund and the World Bank).

As a country liberalises its trade policy regime, policy change usually occurs in three distinct areas: physical trade, financial flows and sectoral liberalisation. The most obvious policy changes relate to reductions in barriers to import of goods (e.g. tariff reduction). However, trade liberalisation also includes export promotion, reducing restrictions on company ownership, financial flows and trade in services, implementing customs reforms and laws regarding equality of treatment (both for firms and countries).

The present paper articulates the pathways through which policies of trade liberalisation influence diets in developing countries, in order to enable public health nutritionists to interpret the dietary implications of trade policy making. As negotiations continue to seek resolution regarding the WTO's Doha Development Agenda, public health nutritionists need to be aware of the variety of ways that trade liberalisation relates to, and shapes, the nutrition transition in developing countries. Two-thirds of the WTO membership is comprised of developing countries ${ }^{(14)}$. These countries often lack wide-ranging technical expertise with regard to the broader implications of trade liberalisation policies, and as such risk entering into trade liberalisation commitments with little understanding of the implications of doing so. In addition, developing countries have often borne the brunt of the unintended consequences of trade liberalisation ${ }^{(15)}$. The analysis in the present paper focuses on the direct effects of trade policies on the food and nutrition system, and proximal factors relating to consumption in developing countries. In this context, the food system refers to processes prior to the consumer that shape the context for consumption - in particular, food production, trade, processing and retail $^{(16-18)}$. There are also important indirect effects of trade liberalisation on nutrition, such as those mediated through impacts on poverty, displacement, income, intellectual property rights relating to plants and working conditions, which have been elucidated elsewhere ${ }^{(1,4)}$.

\section{Method}

The key agreements of the WTO ${ }^{(19,20)}$ were used to develop a map of pathways through which trade liberalisation impacts upon dietary change. A systematic search of the health-related literature was conducted to identify relevant literature (primarily through PubMed and Google Scholar), using the search terms 'nutrition' and/or 'food', with 'trade', 'liberalisation', 'foreign direct investment', 'communications', 'finance', 'exchange rate', 'tourism' and 'trade in services'. After reviewing this literature, together with food and nutrition system frameworks $^{(16-18)}$, the agreements of the WTO were reviewed with a focus on their implications for nutrition transition. In assessing these agreements - particularly the General Agreement on Tariffs and Trade (GATT), the General Agreement on Trade in Services (GATS), the agreement on Trade-Related Intellectual Property Rights (TRIPS), the agreement on Trade-Related Investment Measures (TRIMS) and the Agreement on Agriculture (AoA) - policy directions with potential to affect the food environment were identified (namely, trade in food, domestic production, investment and trade in services). The literature regarding the food system and trade/food was then used to trace pathways of influence from policy change associated with trade liberalisation, to impacts on the food environment/ food system, through to changes in food consumption patterns relative to the nutrition transition. Case studies encountered through the literature search were used to illustrate and further elucidate these pathways.

\section{Pathways}

Figure 1 articulates the pathways through which trade liberalisation policies can affect food consumption in relation to the nutrition transition. The following section of the paper discusses each component of Fig. 1 in detail, examining the implications of trade in goods, export promotion, investment and trade in services and support/ protection for local production and industry.

\section{Trade in goods}

\section{Import facilitation}

From the WTO's point of view, the main barriers to trade in goods under a 'protectionist' policy framework are tariffs and 'non-tariff barriers to trade' (see glossary, Box 1). Tariffs are seen as the least trade distorting measure - they simply increase the price of goods - whereas quotas and unnecessary regulatory restrictions are perceived by advocates of free trade as highly trade distorting because they prevent (international) supply from responding completely to (domestic) demand. The WTO agreements designed to liberalise trade in goods address these barriers. The key agreement is the GATT, which was revised in 1994 as part of the Uruguay round. Attached to this agreement are 'schedules' - a list of commitments by countries regarding when they will reduce their tariffs, and specifying the reductions. The AoA specifies reductions in relation to agricultural commodities, as well as 'tariffication' (21). In the Sanitary and Phytosanitary Measures (SPS) and Technical Barriers to Trade (TBT) Agreements, countries commit to eliminating restrictions and import regulations that are disguised protectionist measures ${ }^{(22,23)}$. These agreements include general principles that help to enable trade in goods. In particular, the 


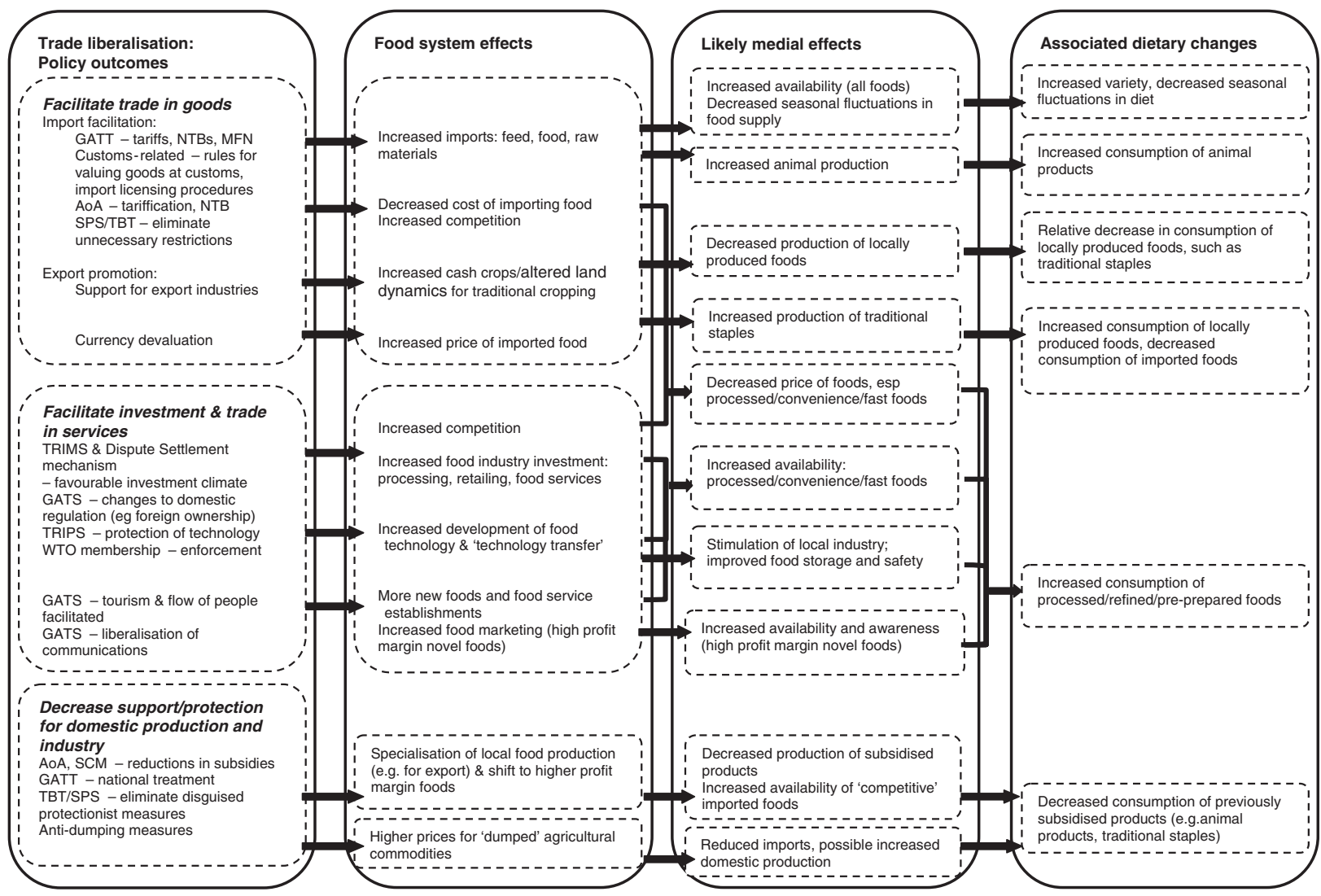

Fig. 1 Pathways for the impact of trade liberalisation policies on population nutrition (GATT, General Agreement on Tariffs and Trade; NTB, Non-Tariff Barriers; MFN, Most Favoured Nation; AoA, Agreement on Agriculture; SPS, Sanitary and Phytosanitary measures; TBT, Technical Barriers to Trade; TRIMS, Trade-Related Investment Measures; GATS, General Agreement on Trade in Services; TRIPS, Trade-Related Intellectual Property Rights; SCM, Subsidies and Countervailing Measures)

Most Favoured Nation principle dictates that all nations should be given equal treatment, meaning that countries cannot use trade barriers to discriminate based on the source of imports. There are also agreements that are designed to improve the efficiency and transparency of customs procedures, thus reducing corruption and making it easier to import and export goods ${ }^{(19)}$

Removing barriers to imports has two key implications for the food environment. Firstly, it generally increases the overall amount of food, feed and raw materials imported into a country. While internationally compiled statistics suggest that the overall volume of imports has been small in comparison to domestic production ${ }^{(24)}$, which has increased due to agricultural advances, the key issue with food imports appears to be the types of foods imported and the associated shifts in food culture. Imports of high value (e.g. meat, dairy and fruit) and processed foods into developing countries have risen dramatically in the past 15 years, while trade in cereals has declined ${ }^{(24)}$. This reflects consumption changes observed with the nutrition transition. Rising imports and decreased cost of animal feed (in many cases, from developed countries with subsidised production) has increased the availability of feed in developing countries and facilitated increased animal production at a lower cost, leading to higher levels of consumption ${ }^{(25)}$. On one hand, this has improved the protein intake to better levels in countries where undernutrition has been a problem, but on the other, intakes of animal products have risen beyond this in many countries, to levels associated with the nutrition transition ${ }^{(26)}$. In addition, with rising openness to international trade, cases of 'dumping' of lowquality foods associated with the nutrition transition have been observed, such as high-fat mutton flaps and turkey tails in the Pacific ${ }^{(6,27)}$. Secondly, by reducing customs charges in the form of tariffs and also possible costs associated with corruption, policies associated with trade liberalisation decrease the cost of importing foods, and thus increase competition for local food producers.

Take the case of China, where rapid nutritional changes have been observed over the past two decades. Between 1989 and 1993, there was a significant trend towards a reduced consumption of grains, tubers and corn products, and an increase in consumption of meat and meat products, eggs and oils ${ }^{(28)}$. Consumer surveys also indicate rising consumption of dairy products, meat and vegetables since the early 1990s (with concomitant growth in market opportunities) ${ }^{(29,30)}$. Over this period, 


\section{Box 1 Glossary of trade terms}

Accession: The process of a country becoming a member of an international agreement, such as the WTO. Negotiations determine the specific obligations a non-member country must meet before it is entitled to full WTO membership benefits.

Foreign direct investment: Investment of foreign assets into domestic structures, equipment, and organisations, involving control of an enterprise by an investor.

Non-tariff barriers to trade: Government measures other than tariffs that restrict trade flows. Examples of nontariff barriers include quantitative restrictions, import licensing, variable levies, import quotas and technical barriers to trade.

Quotas: Quantitative restrictions (commonly known as import quotas) are used to control the number of foreign products that can enter the domestic market.

Tariffs: Customs duties on merchandise imports by weight or volume.

Tariffication: The conversion of non-tariff barriers into tariffs.

Tariff-rate quota: Application of a higher tariff rate to imported goods after a certain quantitative limit (quota) has been reached. A lower tariff rate applies to any imports below the quota amount.

Trade barriers: Regulations used by governments to restrict imports from, and exports to, other countries. Examples include tariffs and 'non-tariff barriers', such as embargoes, and import quotas, import licensing systems, sanitary regulations, or prohibitions.

Trade liberalisation: The reduction of tariff and non-tariff barriers to trade and other forms of commercial interaction.

World Trade Organization: The international organisation dealing with the rules of trade between nations. It provides a forum for development of trade relations between countries, through collective debate, negotiation, and adjudication, as well as the principal contractual obligations ('agreements') determining how governments frame and implement domestic trade legislation and regulations.

Source: WTO Glossary (http://www.wto.org/english/thewto_e/glossary_e/glossary_e.htm).

there were also significant changes in trade policy. Tariff and non-tariff barriers fell markedly during the late 1980s, with sharp reductions for agricultural products in the early 1990s. Food import data suggest that trade in food has contributed to the changing availability of foods associated with the nutrition transition in China (Fig. 2).

\section{Export promotion}

Export promotion is also an important component of trade liberalisation. These policies focus on support for export industries, facilitated by the International Trade Centre (a joint cooperation agency of the United Nations Conference on Trade and Development and WTO for trade promotion and export development, created in 1964) ${ }^{(32)}$. Support for export industries over the years has increased the use of land for 'cash crops' - crops for export - in many developing countries. In some cases, this means a smaller amount of land available for traditional, domestic crops, and in others, fewer farmers to grow crops for domestic production, resulting in decreased production of traditional starchy staples ${ }^{(33,34)}$. For example, the promotion of crops for export in most African nations has been an ongoing policy focus since the mid-20th century. While this has had a range of social

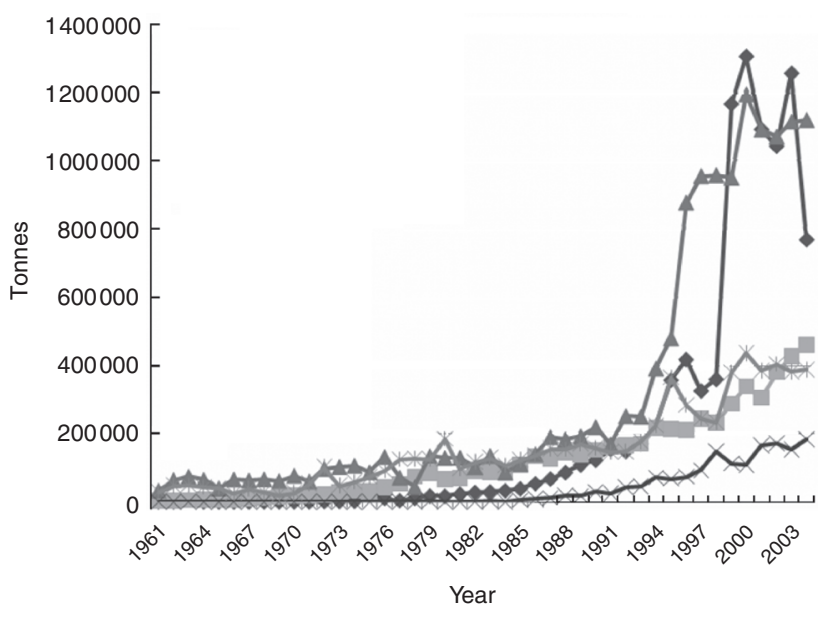

Fig. 2 Imports of some key foods into China, 1961-2004. Source: FAOSTAT Trade Data ${ }^{(31)}(\multimap$, meat and meat preparations; $-\div$, dairy products + eggs; $\multimap$, fruits excluding melons, total; $\longleftarrow$, vegetables primary; $\longleftarrow$, animal fats)

implications in the context of colonialism, it has also led to changes in patterns of food consumption that appear to support the nutrition transition; in particular, increasing 
consumption of Western cereals, animal products and processed foods. In many cases, production of cash crops has been at the expense of traditional staple grains, leading to decreased production and consumption ${ }^{(35,36)}$. In other areas, where there has been a lesser impact on production, there has nevertheless been a loss of the prestige of traditional crops ${ }^{(35,37)}$. The implications of these changes are devastating in a region still affected by high levels of hunger and under-nutrition. Similarly, Cassels describes the nutritional implications of the sale of fishing rights in Micronesia ${ }^{(5)}$. In this situation, development of the tuna export industry - largely through foreign investment - has limited local access to fresh fish, and also has limited local workforce development.

Currency devaluation can also be used as a strategy to make exports more attractive by decreasing the cost for purchasing countries (i.e. other countries pay less for the same amount of goods), and is usually implemented as part of an economic growth strategy. However, it also increases the cost of imports domestically. This can affect local diets in two ways: if domestic production is limited, or consumed by export crop production, currency devaluation can increase the cost of food and reduce overall food consumption and dietary diversity, as occurred in Senegal and the Congo in response to a $50 \%$ currency devaluation $1994^{(37)}$. However, if domestic production has the capacity to respond, currency devaluation can have positive dietary effects through increasing the availability and consumption of locally produced foods. Papua New Guinea's Kina was devalued by around $66 \%$ during the 1990s, resulting in the price of locally grown staples, such as sweet potato, becoming more competitive with imported rice and flourbased foods. Rural food producers responded to increased demand for locally grown food by increasing production. Subsequently, decreased consumption of imported foodstuffs was observed, in conjunction with increased sales of domestically produced traditional crops $^{(38)}$.

\section{Investment and trade in services}

Policies associated with trade liberalisation also act to encourage investment, as a means to economic growth ${ }^{(19)}$. One of the key WTO agreements is the GATS ${ }^{(39)}$, which includes changes in regulations such as reductions in restrictions on foreign ownership of companies. Such regulatory change is enhanced by improved protection of intellectual property rights (e.g. brand names) under the TRIPS Agreement ${ }^{(40)}$. In addition, the TRIMS Agreement contains commitments to remove any restrictions on where companies source their inputs (e.g. domestically rather than from imports) ${ }^{(41)}$. A key principle of these agreements is 'national treatment', which means that foreign companies receive the same treatment as domestic companies. In addition, as members of the WTO, countries have access to dispute settlement and enforcement mechanisms, which make the global investment situation much more secure and predictable ${ }^{(19)}$.
As policies to encourage investment have been implemented in developing countries, a high proportion of food-related foreign direct investment (FDI) has been implemented by food processors and retailers. The dramatic increases in FDI into food processing and supermarkets have been seen to facilitate the nutrition transition through increasing production and availability of processed foods in developing countries ${ }^{(42,43)}$. Such investment has made highly processed foods more readily available to consumers because of local production and the bias of multinational retailers to stock processed foods with a long shelf life and minimal wastage $^{(43,44)}$. It has also made it possible for international processors to cut costs associated with transporting the finished product, increasing their local competitiveness and reducing prices. For example, during the late 1980s and early 1990s, Mexico undertook significant trade policy liberalisation - most notably, signing the North American Free Trade Agreement (NAFTA) in 1992. By 1993, Mexico permitted $100 \%$ foreign ownership of firms in most sectors of the economy ${ }^{(45)}$. Between 1987 and 1997, sales by US-owned food processing affiliates in Mexico grew $477 \%$, with the majority of production for the local market ${ }^{(46)}$. The USA remains the major source of FDI in processed food, and rapid growth has continued, particularly for snacks, dairy products and baked goods ${ }^{(47)}$. These changes in availability of processed foods and beverages in Mexico have been reflected in the observed increase in their consumption ${ }^{(48)}$.The dramatic increase of FDI into food retail in Brazil during the 1990s - equivalent to supermarket growth over five decades in the USA - was also a direct response to liberalisation of regulations relating to investment ${ }^{(49)}$. The entry of multinational retailers into Brazilian markets has increased competition and reduced prices, particularly for processed foods, for which large retailers have an advantage due to economies of scale ${ }^{(50)}$. In turn, rising consumption of processed foods has been observed during the 1990s in conjunction with rising consumption of fat and sugar, and declining consumption of traditional cereals and beans in Brazil ${ }^{(51)}$.

Investment in tourism-related industries is also supported by GATS through easing restrictions relating to the flow of people, and thus facilitating consumption abroad and access to tourist destinations ${ }^{(19)}$. The implications of this for food relate to the introduction of non-traditional foods to cater for tourists, as well as changes to agriculture as a result of a shift to a service economy. This has been noted in the Mediterranean, where some countries have experienced high levels of tourism and others have not. For instance, despite being a Mediterranean country, observers have noted that the modern Maltese diet resembles a northern European diet much more closely than it does a Mediterranean diet. Investigations into the reason for these dietary patterns suggest that the high level of tourism since independence (e.g. compared to 
levels in Sardinia) have played a role. This relationship has been mediated both via the introduction of new foods and by the demands of the tourism industry on domestic production $^{(52,53)}$.

As an outcome of reducing restrictions on foreign ownership of companies, the developing world has also seen an increase in investment by advertising corporations. In conjunction with changes to industry and retailing as liberalisation has progressed, there have also been specific measures in trade agreements that open advertising markets $^{(7)}$. This has resulted in an advertising environment that encourages consumption of heavily promoted foods, the most heavily marketed being pre-sugared breakfast cereals, soft drinks, confectionery, savoury snacks and fastfood outlets ${ }^{(54)}$. For example, with liberalisation in India during the 1990s, changes were noted in the content and context of advertising as it became more 'Westernised', increased in volume and became increasingly dominated by multinational companies - both the advertising companies themselves and the companies advertising their products ${ }^{(55,56)}$. In terms of food, this was associated with increasing advertisement of soft drinks and fast foods. There is a particularly high level of competition between Coke and Pepsi for the soft drink market, reflected in aggressive advertising (mainly to youth) and very low prices ${ }^{(57)}$. These observations are consistent with observed dietary changes associated with obesity among Indians in higher socio-economic groups ${ }^{(58)}$.

\section{Support/protection for local production and industry}

Advocates of trade liberalisation argue that support and protection for local food producers and industry - such as subsidies for farmers, or high import tariffs on foods which are also produced locally - act to distort trade because prices and availability do not accurately reflect demand. In other words, the food supply is responding instead to the presence of subsidies, or to added costs (tariffs) associated with importing food. As such, part of trade liberalisation is to reduce false incentives for production, and ensure that industry is competitive in an international arena.

Under the AoA, developing countries agreed to cut subsidies by $13 \%$, and as part of the Agreement on Subsidies and Countervailing Measures the use of subsidies is regulated and countries are permitted to take action against other countries using subsidies ${ }^{(59)}$. Prohibited subsidies are those that are attached to conditions such as the use of domestic materials by industry. Other subsidies ('actionable' and 'non-actionable') can be contested only if another member country believes that they are adversely affecting their interests. Local support can also take the form of unnecessary technical restrictions on imports that act to reduce trade. The SPS and TBT agreements address these kinds of restrictions, and have been discussed before, along with the impact of the removal of protectionist tariffs on incentives for food consumption. This section will therefore focus on removal of subsidies.

With the elimination of prohibited subsidies, food processors are no longer bound to sourcing inputs domestically and thus have the option to source cheaper inputs internationally, thus reducing overall cost of processed foods. Removing such restrictions may also increase the attractiveness of investment into the food industry, thus magnifying the effects of investmentrelated measures discussed earlier.

The implications of removal of agricultural subsidies are less clear, as the level of subsidisation of agricultural and other food production varies widely between developing countries. In fact, the highest levels of agricultural subsidies are found in the USA and Europe. Thus, removal of subsidies in developed countries might have a larger impact on developing countries, because it would increase the cost and decrease the volume of imports of highly subsidised products ${ }^{(60)}$. This removal of subsidies, combined with the ability of WTO members to implement anti-dumping measures ${ }^{(61)}$, would reduce the problem of 'dumping' of low-priced agricultural goods on developing country markets ${ }^{(62)}$. Reductions in subsidies for production in developing countries have the potential to affect domestic food availability and price through changing incentives for production. However, there is little available literature on the outcome of such policy changes for diet.

The impact of the removal of subsidies on diets depends strongly on the nature of the products subsidised. For example, if traditional crops have been subsidised and these subsidies are removed, producers of traditional crops may shift to crops for export - an effect potentially compounded by policies promoting export ${ }^{(63)}$. This may contribute to a decline in availability of traditional foods and consequent increasing consumption of imported foods, as discussed before. However, if subsidised production is of animal products, or even of vegetable oils as is the case in South America ${ }^{(64)}$, then removal of subsidies would correct distortions that are promoting high-fat diets, which was the case in Poland. With Poland's transition to a market economy in the early 1990s came swift reductions in agricultural subsidies. This increased costs for dairy and beef production - translating to a reduction in availability and increase in purchase cost for consumers ${ }^{(65,66)}$. Resultant changes to food consumption patterns contributed to a reduction in cardiovascular mortality in Poland over the following decade ${ }^{(67)}$.

\section{Discussion}

The illustrated pathways described in the present paper indicate that trade liberalisation can have both positive and negative influences on consumption patterns related to the nutrition transition. The trade liberalisation agenda 
has in some ways skewed incentives for food consumption, with some 'unhealthier' foods associated with the nutrition transition becoming increasingly cheaper and more readily available. Availability and affordability of processed foods, meat and dairy are often improved with reductions in tariffs and the increased investment in processing and retail. These foods have been highlighted as critical contributors to rising salt, fat and sugar intakes. These changes in relative food availability and price, described in the pathways earlier, are also likely to be more significant for the poor, who are in turn less able to access health-care services and thus more vulnerable to morbidity and mortality due to chronic diseases ${ }^{(11)}$. However, trade liberalisation can also have positive dietary implications. For example, currency devaluation can stimulate domestic (traditional) food consumption, and removal of subsidies can reduce the availability and affordability of fats and oils.

The clear pathways and examples of positive outcomes described here suggest that there are a variety of opportunities for public health nutritionists to promote good nutrition by seeking to minimise negative outcomes and make the most of any positive outcomes. For example, an understanding of the pathways can be used to identify the nutritional implications of proposed trade policy changes, thus equipping nutritionists to advocate for policy modifications at the draft or development stage, or to propose policies to mitigate the possible nutritional impacts. For instance, as a country reduces barriers to trade in foods, nutritionists could advocate for food composition standards that would restrict availability of high-fat foods, as Lawrence ${ }^{(68)}$ proposes for the Pacific, or launch a campaign to promote healthy food consumption.

A better understanding of the implications of trade liberalisation for diets also equips public health nutritionists to advocate for global changes to trade policy and the WTO agenda, such as the need for developed countries to remove agricultural subsidies. In terms of national advocacy, there is potential to equip and influence trade policy makers at both a national and global level to promote 'healthy' trade policy. Within the WTO agreements, there is scope for influencing trade policy change in such a way as to promote health - not least due to the growing recognition that developing countries require flexibility beyond that of the developed world as they pursue trade liberalisation ${ }^{(19)}$. Much of this scope is during negotiation of trade agreements ${ }^{(3)}$, for example, negotiations between country and working party in WTO accession, bilateral or regional FTA negotiation, or multilateral negotiation that takes place between members of the WTO. Article 20 of the GATT allows governments to enforce barriers to trade that protect human health, and rulings in favour of protection of health as an 'interpretive principle' for WTO agreements have also been observed during trade disputes ${ }^{(69)}$.

\section{Conclusions}

The present paper has delineated pathways through which trade policies associated with liberalisation shape incentives for food consumption, thereby providing evidence for trade policy as a macro-level influence on dietary change in developing countries. These pathways and illustrative case studies demonstrate the complex yet clearly influential relationship between trade policies associated with liberalisation, and food consumption patterns relating to the nutrition transition. It is evident that this influence can have both positive and negative ramifications for population food consumption.

The present paper thus enables public health nutritionists to interpret the implications of trade policy making for diets. Though this paper has documented a range of unintended consequences of trade policy making for nutrition in developing countries, the actual use of trade policy as a tool for improving diets requires a sophisticated approach. As raised previously, addressing capacity for policy change and development will be critical; developing countries are often significantly less represented at trade negotiations than wealthier countries, and thus may have a lower chance of being successful in their negotiations $^{(70)}$. In addition, convincing trade policy makers of the threat presented by chronic disease arising from the nutrition transition presents a challenge, as WTO decision makers have traditionally interpreted only a narrow range of public health concerns as legitimate reasons for trade restrictions $^{(3,71)}$. As a result, more investigation is needed into strategies to minimise the negative impacts of trade on diet, and to play on positive impacts to maximise their effect in order to advance policy making in this area.

\section{Acknowledgements}

The present paper will form part of my PhD thesis, the research for which is funded through an Australian Postgraduate Award. I have no conflicts of interest to declare. I would like to thank Corinna Hawkes and Stephen Colagiuri for providing valuable conceptual and directional input, and Stephen Leeder for his supervisory role and editorial comments. I would also like to thank the anonymous reviewers for their very constructive input.

\section{References}

1. Schaffer ER, Waitzkin H, Brenner J \& Jasso-Aguilar R (2005) Global trade and public health. Am J Public Health 95, 23-34.

2. Bettcher DW, Yach D \& Guindon GE (2000) Global trade and health: key linkages and future challenges. Bull World Health Organ 78, 521-534.

3. World Health Organization and World Trade Organization (2002) WTO Agreements and Public Health: A Joint Study by the WHO and WTO Secretariat. Geneva: WTO/WHO. 
4. Blouin C, Chopra M \& van der Hoeven R (2009) Trade and health 3: trade and the social determinants of health. Lancet 373, 502-507.

5. Cassels S (2006) Overweight in the Pacific: links between foreign dependence, global food trade and obesity in the Federated States of Micronesia. Global Health 2, 10.

6. Evans M, Sinclair RC, Fusimalohi C \& Liava'a V (2001) Globalization, diet and health: an example from Tonga. Bull World Health Organ 79, 856-862.

7. Hawkes C \& Thow AM (2008) Implications of the Central America-Dominican Republic-Free Trade Agreement for the nutrition transition in Central America. Rev Panam Salud Publica 24, 345-360.

8. Rayner G, Hawkes C, Lang T \& Bello W (2006) Trade liberalization and the diet transition: a public health response. Health Promot Int 21, Suppl. 1, 67-74.

9. Caballero B \& Popkin BM (editors) (2002) The Nutrition Transition: Diet and Disease in the Developing World. London: Elsevier Science.

10. Popkin B (2002) An overview on the nutrition transition and its health implications: the Bellagio meeting. Public Health Nutr 5, 93-103.

11. World Health Organization (2005) Preventing Chronic Disease: A Vital Investment. Geneva: WHO.

12. World Health Organization (2003) Diet, Nutrition and the Prevention of Chronic Diseases. Joint WHO/FAO Expert Consultation. Geneva: WHO.

13. World Bank (2006) Repositioning Nutrition as Central to Development: A Strategy for Large-Scale Action. Washington, DC: The World Bank.

14. Rekas M (2006) Developing Countries Find Voice in Hong Kong. http://www.fas.usda.gov/info/fasworldwide/2006/ 02-2006/WTOHongKongMinisterial.htm (accessed March 2008).

15. Labonté R \& Schrecker T (2007) Globalization and social determinants of health: promoting health equity in global governance (part 3 of 3). Global Health 3, 7.

16. Cawley J (2004) An economic framework for understanding physical activity and eating behaviors. Am J Prev Med 27, Suppl. 3, 117-125.

17. Sobal J, Khan LK \& Bisogni C (1998) A conceptual model of the food and nutrition system. Soc Sci Med 47, 853-863.

18. Heywood P \& Lund-Adams M (1991) The Australian food and nutrition system: a basis for policy formulation and analysis. Aust J Public Health 15, 258-270.

19. World Trade Organization (2007) Understanding the WTO. Geneva: WTO.

20. World Trade Organization (1994) Uruguay Round Agreements. http://www.wto.org/english/docs_e/legal_e/legal_e. htm (accessed March 2008).

21. World Trade Organization (1994) Agreement on Agriculture. Geneva: WTO.

22. World Trade Organization (1994) Agreement on Sanitary and Phytosanitary Measures. Geneva: WTO.

23. World Trade Organization (1994) Agreement on Technical Barriers to Trade. Geneva: WTO.

24. Food and Agricultural Organization (2004) The State of Agricultural Commodity Markets. Rome: FAO.

25. Nugent R (2004) Food and agriculture policy: issues related to prevention of noncommunicable diseases. Food Nutr Bull 25, 200-207.

26. Popkin BM (1998) The nutrition transition and its health implications in lower-income countries. Public Health Nutr 1, 5-21.

27. Schoeffel P (1992) Food, health and development in the Pacific Islands: policy implications for Micronesia. J Micronesian Stud 1, 223-250.

28. Zhang X (2002) The dynamics of Chinese consumers: a case of Shanghai food consumption. J Int Food Agribusiness Mark 14, 47-66.
29. Lardy NR (2003) Trade liberalization and its role in Chinese economic growth. http://www.imf.org/external/np/apd/ seminars/2003/newdelhi/lardy.pdf (accessed March 2008).

30. Huang J \& Rozelle S (2001) Trade Liberalization, WTO and China's Food Economy in the 21st Century: Larger, Modest, or Little Impacts? Trade Working Papers no. 191. Canberra: East Asian Bureau of Economic Research.

31. Food and Agricultural Organization (2007) FAOSTAT trade data, TradeStat detailed trade data. http://faostat.fao.org/ site/535/DesktopDefault.aspx?PageID = 535 (accessed July 2007).

32. World Trade Organization (2009) The WTO and the International Trade Centre (UNCTAD/WTO). http://www. wto.org/english/thewto_e/coher_e/wto_itc_e.htm (accessed February 2009)

33. Thaman RR \& Thomas PM (1985) Cassava and change in Pacific Island food systems. In Food Energy in Tropical Ecosystems, pp. 191-228 [DJ Cattle and KH Schwerin, editors]. New York: Gordon and Breach Science Publishers.

34. Cypher JM \& Dietz JL (2008) The Process of Economic Development, 3rd ed. London: Routledge.

35. Brun TA (1991) The nutrition and health impact of cash cropping in West Africa: a historical perspective. World Rev Nutr Diet 65, 124-162.

36. Raschke V \& Cheema B (2008) Colonisation, the New World Order, and the eradication of traditional food habits in East Africa: historical perspective on the nutrition transition. Public Health Nutr 11, 662-674.

37. Fouéré T, Maire B, Delpeuch F, Martin-Prével Y, Tchibindat F \& Adoua-Oyila G (2000) Dietary changes in African urban households in response to currency devaluation: foreseeable risks for health and nutrition. Public Health Nutr 3, 293-301.

38. Bourke RM (2005) Marketed fresh food: a successful part of the Papua New Guinea economy. Dev Bull 67, 22-24.

39. World Trade Organization (1994) General Agreement on Trade in Services. Geneva: WTO.

40. World Trade Organization (1994) Agreement on Trade Related Aspects of Intellectual Property Rights, Including Trade in Counterfeit Goods. Geneva: WTO.

41. World Trade Organization (1994) Agreement on Trade Related Aspects of Investment Measures. Geneva: WTO.

42. Schmidhuber J \& Shetty P (2005) Nutrition transition, obesity and noncommunicable diseases: drivers, outlook and concerns. SCN News 29, 13-19.

43. Hawkes C (2005) The role of foreign direct investment in the nutrition transition. Public Health Nutr 8 , $357-365$

44. Narsey W (1995) Nutritional development within free markets. Paper presented at the National Nutrition Planning Meeting, 22 November 1995, University of the South Pacific.

45. Handy CR \& Langley S (1993) Food processing in Mexico attracts US investments - Industry Overview. Food Rev 16, $20-24$.

46. Bolling C \& Somwaru A (2001) US food companies access foreign markets through direct investment. Food Rev 24, 23-28.

47. Hawkes C (2006) Uneven dietary development: linking the policies and processes of globalization with the nutrition transition, obesity and diet-related chronic diseases. Global Health 2, 4 .

48. Rivera JA, Barquera S, González-Cossío T, Olaiz G \& Sepulveda J (2004) Nutrition transition in Mexico and in other Latin American countries. Nutr Rev 62, Suppl. 2, S149-SS57.

49. Reardon T, Timmer P \& Berdegue J (2004) The rapid rise of supermarkets in developing countries: induced organizational, institutional and technological change in agrifood systems. Electron J Agric Dev Econ 1, 168-183. 
50. Reardon T, Timmer P, Barrett CB \& Berdegue J (2003) The rise of supermarkets in Africa, Asia and Latin America. Am J Agric Econ 85, 1140-1146.

51. Bermudez OI \& Tucker KL (2003) Trends in dietary patterns of Latin American populations. Cad Saude Publica 19, Suppl. 1, S87-S99.

52. Tessier S \& Gerber M (2005) Factors determining the nutrition transition in two Mediterranean islands: Sardinia and Malta. Public Health Nutr 8, 1286-1292.

53. Mizzi L (1995) Food and nutrition policy in Malta. Food Policy 20, 475-486.

54. Hastings G, McDermott L, Angus K, Stead M \& Thomson S (2007) The Extent, Nature and Effects of Food Promotion to Children: A Review of the Evidence. A Technical Report Prepared for the WHO. Geneva: WHO.

55. Thaman RR (1988) Consumerism, the media, and malnutrition in the Pacific Islands. J Pac Stud 14, 68-90.

56. Ciochetto L (2004). Advertising and globalisation in India. Presented at the 18th European Conference on Modern South Asian Studies, Lund, Sweden, 6-9 July 2004. European Association for South Asian Studies.

57. Mukherji P (1999) The gold rush in modern times: a study of the impact of economic liberalization on the cultural content of Indian advertisements. Master of Arts in Communication, University of Delaware.

58. Griffiths PL \& Bentley ME (2001) The nutrition transition is underway in India. J Nutr 131, 2692-2700.

59. World Trade Organization (1994) Agreement on Subsidies and Countervailing Measures. Geneva: WTO.

60. Aksoy A \& Beghin JC (editors) (2005) Global Agricultural Trade and Developing Countries. Washington, DC: World Bank.

61. World Trade Organization (1994) Agreement on Implementation of Article VI (Anti-dumping). Geneva: WTO.

62. Watkins K \& von Braun J (2003) Time to Stop Dumping on the World's Poor. 2002-2003 IFPRI Annual Report Essay.
Washington, DC: International Food Policy Research Institute.

63. Meliczek H (1996) Agrarian Reform and Rural Development Strategies in the Post-Cold War Era (Rural Development International Workshop). W4760/E. Rome: UN Food and Agricultural Organization.

64. Drewnowski A (2000) Nutrition transition and global dietary trends. Nutrition 16, 486-487.

65. Kwiecinski A \& Leopold A (1993) Polish agriculture during the transition period. In Stabilization and Structural Adjustment in Poland, pp. 206-218 [H Kierzkowski, M Okolski and S Wellisz, editors]. London: Routledge.

66. Zatonski WA, McMichael AJ \& Powles JW (1998) Ecological study of reasons for sharp decline in mortality from ischaemic heart disease in Poland since 1991. Br Med J 316, 1047-1051.

67. Waskiewicz A, Piotrowski W, Sygnowska E, Rywik S \& Jasinski B (2006) Did favourable trends in food consumption observed in the 1984-2001 period contribute to the decrease in cardiovascular mortality? - Pol-MONICA Warsaw Project. Kardiol Pol 64, 16-23.

68. Lawrence M (2003) Using Domestic Law in the Fight Against Obesity: An Introductory Guide for the Pacific. Manila: WHO Regional Office for the Western Pacific.

69. Bloche MG \& Jungmann ER (2007) Health policy and the World Trade Organization. In Globalization and Health, pp. 250-267 [I Kawachi and S Wamala, editors]. New York: Oxford University Press.

70. Kelsey J (2004) Big Brothers Behaving Badly: The Implications for the Pacific Islands of the Pacific Agreement on Closer Economic Relations (PACER). Suva, Fiji: Pacific Network on Globalisation.

71. Beaglehole R \& Yach D (2003) Globalisation and the prevention and control of non-communicable disease: the neglected chronic diseases of adults. Lancet 362, 903-908. 